\title{
Nutrient control of algal growth in estuarine waters. Nutrient limitation and the importance of nitrogen requirements and nitrogen storage among phytoplankton and species of macroalgae
}

\author{
Morten Foldager Pedersen*, Jens Borum
}

Freshwater Biological Laboratory, University of Copenhagen, Helsingørsgade 51, DK-3400 Hillerød, Denmark

\begin{abstract}
Nutrient enrichment of shallow coastal waters changes the composition of plant communities so that slow-growing, benthic macrophytes are replaced by fast-growing algae such as phytoplankton and ephemeral macroalgae. This scenario suggests that fast-growing algae suffer more from nutrient limitation than slow-growing algae at low nutrient availability. We tested this hypothesis by comparing the effect of in situ nutrient enrichment on the phytoplankton community, 4 ephemeral macroalgae (Ulva lactuca, Cladophora serica, Chaetomorpha linum and Ceramium rubrum) and 1 perennial macroalga (Fucus vesiculosus). Nitrogen was the main limiting nutrient to algal growth and fast-growing algae were $N$ limited for a longer period during summer than slower-growing species. Differences in the temporal extent of $\mathrm{N}$ limitation were related to species-specific variations in $\mathrm{N}$ requirements for growth and in $\mathrm{N}$ storage pools. The $\mathrm{N}$ requirements per unit biomass and time were up to 30 -fold higher for fast-growing algae compared to slow-growing species due to 10 -fold faster growth and 3 -fold higher demands for the internal $N$ concentration needed to sustain maximum growth (i.e. critical concentrations). The pools of $\mathrm{N}$ reserves only varied 2 -fold among algal species and could support maximum growth for $0.5 \mathrm{~d}$ in the phytoplankton community and for $12 \mathrm{~d}$ in $F$. vesiculosus. Growth of phytoplankton and $F$. vesiculosus could proceed at reduced rates for another 2.6 and $34 \mathrm{~d}$, respectively, based on other internal pools of $N$. The results suggest that the species-specific differences in growth rate and critical $N$ concentrations account for a substantial part of the variation in the duration of nutrient limitation among different algal types and, therefore, provide further clarification of the reasons why fast-growing algae are stimulated by increased nutrient availability while slowgrowing algae remain unaffected or are hampered due to shading.
\end{abstract}

KEY WORDS: Marine algae $\cdot$ Nutrients $\cdot$ Nutrient dynamics $\cdot$ Competition

\section{INTRODUCTION}

Increased nutrient loading of shallow coastal areas has marked effects on the composition of autotrophic communities in coastal marine waters (Sand-Jensen \& Borum 1991, Duarte 1995). Coastal waters harbor diverse communities of planktonic and periphytic microalgae, ephemeral and perennial macroalgae and seagrasses, and the dominance among these commu-

- Present address: Department of Life Sciences and Chemistry 17.2, University of Roskilde, Box 260, DK-4000 Roskilde, Denmark. E-mail: mfpedersen@dk-online.dk nities is controlled by an array of factors, such as morphometry, exposure to waves and currents, substratum composition, grazing, light and nutrient availability working alone or in complex interactions as reviewed by Sand-Jensen \& Borum (1991). Increased nutrient richness of estuarine ecosystems stimulates the abundance and production of fast-growing algae such as phytoplankton, epiphytic algae and ephemeral macroalgae (Boynton et al. 1982, Borum 1983, 1985, Twilley et al. 1985, Sfriso et al. 1987, Fong et al. 1993, Neundorpher \& Kemp 1993, Taylor et al. 1995) and shading by these components reduces the abundance of slowgrowing, benthic macrophytes such as seagrasses and 
kelps (Brinkhuis 1977, Orth \& Moore 1983, Cambridge \& McComb 1984, Kautsky et al. 1986, Burkholder et al. 1992). This scenario suggests that the growth and biomass development of fast-growing plants are restricted more by low nutrient availability during summer than are the growth and biomass development of large, slow-growing macrophytes, which seem able to satisfy their nutrient requirements and sustain close to maximum growth rates during periods of low nutrient availability.

The suggested difference in nutrient dependence among various plant types may be explained by interspecific differences in nutrient requirements. Large, long-living algae typically have low nutrient requirements per unit biomass and time compared to phytoplankton and ephemeral macroalgae because large, long-living algae have low growth rates (doubling times of weeks to months; Nielsen \& Sand-Jensen 1990) and low tissue nutrient concentrations (Duarte 1992). The larger and more morphologically complex plant types, such as most seagrasses and fucoid macroalgae, may reduce their demand for nutrients further by continuously allocating tissue nutrients to the metabolically active tissues (i.e. the meristems) while supportive tissues have low nutrient concentrations (Pedersen \& Borum 1992). Large, slow-growing plants can thereby lower the tissue nutrient concentrations needed to sustain maximum growth (i.e. the 'critical nutrient content', sensu Hanisak 1979) compared to unicellular algae and ephemeral macroalgae with less differentiated thalli.

Differences in the efficiency of nutrient acquisition could also explain the variation in nutrient dependence among slow-and fast-growing plants. Nutrient requirements ultimately have to be met by uptake from the surrounding medium, and the uptake by micro- and macroalgae seems to follow general allometric rules where size, growth rate, loss rate and metabolic rates are appropriately scaled (Odum et al. 1958, Banse 1976, Littler \& Littler 1980, Smith \& Kalff 1982, Cebrián \& Duarte 1994, Hein et al. 1994). During periods of high nutrient availability and low light, however, all plants take up nutrients in excess of immediate demands, building up internal stores which can be utilized during subsequent periods of low nutrient availability and high light (Chapman \& Craigie 1977. Zimmerman \& Kremer 1986, Pedersen \& Borum 1993). Assuming that all algal cells can accumulate the same amount of nutrients per unit of biomass, then slowgrowing algae with low critical nutrient concentrations should be able to build up larger nutrient reserves than fast-growing algae with high critical nutrient concentrations. The slow growth of large, long-living algae implies that accumulated nutrients can support maximum growth for a longer period of time when external nutrient availability is low, giving slow-growing algae a competitive advantage in areas where the nutrient availability fluctuates

Here, we evaluate the hypothesized nutrient control of algal growth. We examined the seasonal changes in algal growth and nutrient content, the temporal extent of nutrient limitation, and interspecific differences in nutrient requirements and storage capacities among the phytoplankton community, 4 ephemeral macroalgae (Ulva lactuca, Chaetomorpha linum, Cladophora serica and Ceramium rubrum) and 1 perennial macroalga (Fucus vesiculosus) representing autotrophs of different size, tissue differentiation and maximum growth rate.

\section{METHODS}

Study site. The study was carried out (and plants for laboratory experiments collected) at Ølsted Strand in. Roskilde Fjord, Denmark. Roskilde Fjord is a eutrophic and shallow estuary (salinity 8 to $17 \%$, mean depth $3 \mathrm{~m})$. The study site was situated along the eastern shore $150 \mathrm{~m}$ from the coast line at a mean water depth of $1.0 \mathrm{~m}(0.2$ to $1.8 \mathrm{~m})$. The area was dominated by patches of Zostera marina and Ruppia maritima on the sandy bottoms while scattered boulders were colonized by dense populations of Fucus vesiculosus. The biomass of drift macroalgae such as Ulva lactuca and Cladophora serica accumulated in spring and early summer and these were succeeded by mats of filamentous Chaetomorpha linum during mid-summer. By late July most ephemeral algae had vanished and only small populations remained until the next spring.

Inorganic nutrients in the water. Triplicate water samples for analysis of dissolved inorganic nutrients $\left(\mathrm{NH}_{4}{ }^{+}, \mathrm{NO}_{3}{ }^{-}\right.$and $\left.\mathrm{PO}_{4}{ }^{3-}\right)$ were collected twice weekly between March and November 1991 Samples were brought back to the laboratory within $1 \mathrm{~h}$, filtered and analyzed for ammonium (Solorzano 1969) and phosphate (Strickland \& Parsons 1968). Sub-samples for nitrate analysis were frozen for later analysis on an Auto Analyzer ${ }^{\boxplus}$ (Alpha Chem)

Growth and enrichment experiments. Growth rates of the phytoplankton community, Ulva lactuca, Cladophora serica, Ceramium rubrum, Chaetomorpha linum and Fucus vesiculosus were measured in situ 8 to 10 times between March and November 1991 Net growth of the phytoplankton community was estimated from changes in biomass upon incubation in 201 translucent polyethylene carboys. Sea water was collected at the study site and filtered through a $200 \mu \mathrm{m}$. Nitex net to reduce macrozooplankton grazing Three carboys without nutrient enrichment were control treatments, 3 were enriched with $400 \mu \mathrm{mol}$ 


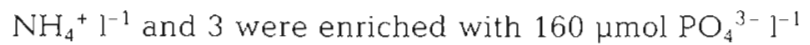
The carboys, 1 of each treatment, were anchored in 3 groups ca $100 \mathrm{~m}$ apart floating just below the water surface. The carboys were collected after $4 \mathrm{~d}$ of incubation and the water was analyzed for dissolved and particulate nutrients, particulate carbon and chlorophyll $(a+b)$ (Wintermanns \& De Motts 1965). The apparent net growth rate $(\mu)$ of the phytoplankton community was calculated from changes in the chlorophyll biomass:

$$
\mu=\left(\ln B_{t}-\ln B_{0}\right) t^{-1}
$$

where $B_{0}$ represents the initial and $B_{\text {q }}$ the final biomass after $t$ days' incubation. Changes in chlorophyll do not give a completely true description of growth, but we preferred to use chlorophyll in our growth estimates because it is a more specific parameter for algae than particulate carbon or nutrients. No attempts were made to describe the qualitative composition of the phytoplankton community or to quantify changes in biovolumes

The growth rates of the 4 ephemeral macroalgae and Fucus vesiculosus were determined on healthy specimens collected at the study site. The algae were rinsed and cut into pieces of approximately $1 \mathrm{~g}$ fresh weight (FW). Whole vegetative thalli were used for the 4 ephemeral macroalgae while apical fronds were used for $F$. vesiculosus. The dry weight (DW) to FW ratio was determined on sacrificed samples and the values were used to convert the measured initial FW of experimental plants to DW. The plants were incubated in the field at $1 \mathrm{~m}$ depth in cylindrical plexiglass cages $120 \mathrm{~cm}$ long, $10 \mathrm{~cm}$ in diameter). The cages were closed at both ends with $0.5 \mathrm{~mm}$ mesh to permit water exchange but limit entry of grazers and loss of algal material. Nutrients were added to the cages as agar blocks containing either $128 \mathrm{mmol} \mathrm{NH}_{4} \mathrm{Cl}$ or $149 \mathrm{mmol} \mathrm{KHPO}_{4}$ to be slowly released over ca $10 \mathrm{~d}$. The cages were organized in 3 groups (designated A, B and C, respectively) situated 40 to $50 \mathrm{~m}$ apart. Each group contained 1 control and 1 of each nutrient treatment $(+\mathrm{N}$ and $+\mathrm{P})$. The plants were left to grow for 6 to $14 \mathrm{~d}$ (depending on season), then collected, rinsed of sand and debris and finally freeze dried. Net growth rates were calculated from changes in DW according to Eq. (1), assuming exponential growth

The overall effect of nutrient enrichment and time (season) on growth rates was analyzed for each species by 2-way ANOVA. The effect of nutrient treatment and location in groups was subsequently analyzed for each individual experiment using 2-way ANOVA. Groups were included as a factor in the post hoc analysis because cages within the same group were occasionally covered by drift algae, causing large variations in growth rates among groups. All data were log-transformed before statistical treatment.
Tissue concentrations of $\mathrm{N}$ and $\mathrm{P}$. The $\mathrm{N}$ and $\mathrm{P}$ content in phytoplankton cells could not be determined separately, but particulate $\mathrm{N}$ and $\mathrm{P}$ concentrations were assumed mainly to represent the phytoplankton. Water samples were taken from each carboy before and after the incubation and filtered through GF/C filters. The filters were dried and analyzed for total $C$ and $\mathrm{N}$ using a Carlo-Erba NA-1500 CHN analyzer, and for total $\mathrm{P}$ after wet oxidation with boiling $\mathrm{H}_{2} \mathrm{SO}_{4}$ and spectrophotometric analysis following Strickland \& Parsons (1968). Tissue $\mathrm{N}$ and P normalized to DW were calculated from the $C: N$ and $C: P$ ratios, assuming that the carbon content of the phytoplankton community was $45 \%$ of DW (Reynolds 1984). Subsamples of macroalgae were also analyzed for tissue C, N and P before and after the growth experiments. Samples were cleaned, dried and analyzed using the methods described above. Only control plants were analyzed for both $N$ and $P$, while $N$-enriched plants were analyzed for $\mathrm{N}$ only and P-enriched plants for $\mathrm{P}$ only. The overall effects of nutrient treatment and time (season) on tissue nutrient concentrations were analyzed by 2 -way ANOVA. The effect of nutrient treatment on tissue nutrient concentration was subsequently analyzed for each individual experiment using Student's $t$-test for paired observations. All data were log-transformed before statistical treatment.

Critical tissue $\mathbf{N}$ concentrations. The critical $\mathrm{N}$ concentrations needed to support maximum growth rates of Ulva lactuca, Cladophora serica, Ceramium rubrum and Fucus vesiculosus were experimentally determined in laboratory growth experiments where growth rates $(\mu)$ were measured as a function of tissue $\mathrm{N}$ concentrations. Vegetative thalli were collected in the field and preconditioned in laboratory cultures for 4 to 6 wk before the growth experiments. The cultures were kept under constant light $\left(300 \mu \mathrm{mol} \mathrm{m} \mathrm{m}^{-2} \mathrm{~s}^{-1} \mathrm{PAR}\right.$ in a 16:8 h light:dark cycle) and temperature $\left(15^{\circ} \mathrm{C}\right)$. Nitrogen was added to the cultures as $\mathrm{NH}_{4} \mathrm{Cl}$ from stock solutions at 5 different loadings. The tissue $\mathrm{N}$ concentrations of the culture algae were measured regularly and $\mathrm{N}$ loading rates were adjusted when necessary. The tissue $\mathrm{N}$ concentrations ranged from about 1 to $5 \% \mathrm{~N}$ of DW when the growth experiments were initiated.

The growth experiments were carried out in 0.51 glass bottles containing freshly collected, filtered seawater that had been stripped of dissolved inorganic nitrogen (DIN) by sheets of Ulva lactuca prior to the growth experiments. The water was bubbled with air to ensure water movement and $\mathrm{O}_{2}$ and $\mathrm{CO}_{2}$ equilibrium in the growth bottles. Initial FW was measured on all algal specimens prior to the growth experiments and the DW to FW ratio was determined on subsamples. The algae were grown for 2 to $8 \mathrm{~d}$ during the 
experiment, depending on the growth rate, then harvested and dried to constant weight at $90^{\circ} \mathrm{C}$. The specific growth rate $(\mu)$ was determined from the increase in algal DW assuming exponential growth and calculated according to Eq. (1). Tissue $\mathrm{N}$ concentrations were determined on subsamples before and on all samples after the growth experiments.

The growth rates $(\mu)$ were plotted versus the mean tissue $N$ concentration and data were fitted to the Droop equation (Droop 1983) using non-linear leastsquare regression:

$$
\mu=\mu_{\max }\left(1-N_{\mathrm{Q}} / N\right)
$$

where $\mu_{\max }$ is the maximum growth rate, $N_{\mathrm{Q}}$ is the minimum tissue $N$ concentration needed to sustain growth (the subsistence quota), and $N$ is the actual tissue concentration in the alga. The critical $N$ concentration $\left(N_{C}\right)$ is not represented by a definite value because the growth rate approaches $\mu_{\max }$ asymptotically with increasing $N$ concentration. Therefore, $N_{C}$ was estimated as the tissue $N$ content at which the growth rate was $0.67 \mu_{\max }$ corresponding to the intercept of the 2 lines determined by the maximum growth rate and the initial slope of the curve. The initial slope was approximated as the line going through the points where $\mu=$ 0 and $\mu=0.5 \mu_{\max }$.

Nitrogen storage capacity. The ability of different algal species to accumulate nitrogen was examined by comparing interspecific differences in the maximum tissue $\mathrm{N}$ concentration measured during the field experiments. The $\mathrm{N}$ pool stored in excess of the requirements for maximum growth ( $N$ storage $=N_{S}$ ) was estimated as the difference between maximum $\left(N_{\max }\right)$ and critical $\left(N_{\mathrm{C}}\right) \mathrm{N}$ concentrations and compared among species. The storage capacity $\left(T_{\max }\right)$, defined as the duration (in days) this storage can sustain maximum algal growth without any compensatory $\mathrm{N}$ uptake from the external media, was calculated as:

$$
T_{\max }=\ln \left(N_{\max } / N_{C}\right) \mu_{\max }{ }^{-1}
$$

The maximum growth rate was obtained from the field measurements (controls or enriched) while values for maximum and critical $\mathrm{N}$ concentrations were from field estimates, laboratory experiments or the literature (in the case of $N_{c}$ for phytoplankton). When maximum growth has consumed internal stores of $\mathrm{N}$ below the critical level, growth will, however, continue at declining rates until the subsistence quota $\left(N_{Q}\right)$ is reached. The period of reduced growth $\left(T_{\text {red }}\right)$ based on internal $N$ pools below the critical level $\left(N_{\text {red }}=N_{C}-N_{Q}\right)$ was calculated as:

$$
T_{\text {red }}=\ln \left(N_{C} / N_{Q}\right)\left(0.5 \mu_{\max }\right)^{-1}
$$

assuming a linear decline in growth rate between $N_{C}$ and $N_{Q}$ (thus giving an average growth rate of $0.5 \mu_{\max }$ during this period). Values of $N_{\mathrm{Q}}$ were obtained from the laboratory experiments or the literature (in the case of phytoplankton).

Error estimation. The critical $N$ concentration $\left(N_{C}\right)$, the internal $N$ pools $\left(N_{S}\right.$ and $N_{\text {red }}$ ) and the storage capacities ( $T_{\max }$ and $T_{\text {red }}$ ) were all calculated as combinations of several individual parameters, each measured with their own error. We applied, therefore, the bootstrap procedure (Efron \& Tibshirani 1986) to estimate means and errors for the combined results. All measured values were assumed to be normally distributed with observed means and standard deviations. The mean values of the combined results were computed using Monte Carlo resampling (165 mean values of $\mathrm{n}=3$ ) of the different measured variables. The overall bootstrapped mean values $\left(\bar{x}_{B}\right)$ differed slightly from the mean values obtained by simply combining the parameter values $\left(\bar{x}_{\text {obs }}\right)$, and therefore, we computed the 'bias-adjusted bootstrap means' $\left(\bar{x}_{B, a d j}\right)$ according to Meyer et al. (1986):

$$
\bar{x}_{\mathrm{B}, a d j}=2 \bar{x}_{\mathrm{obs}}-\bar{x}_{\mathrm{B}}
$$

Bias-adjusted $95 \%$ confidence limits were computed from the 2.5 and $97.5 \%$ percentiles of the bootstrapped data sets according to Meyer et al. (1986).

\section{RESULTS}

\section{Nutrient availability}

The concentration of dissolved inorganic $N$ (DIN) was relatively high $(>20 \mu \mathrm{M}$ ) in Roskilde Fjord during winter, in early spring and late autumn, but low $(<2 \mu \mathrm{M})$ from April to October (Fig. 1A). The concentration of dissolved inorganic $P$ (DIP) was low $(<2 \mu \mathrm{M})$ in late April but increased to high levels throughout summer and autumn (range: 2 to $9.5 \mu \mathrm{M}$; Fig. 1B). The molar DIN:DIP ratio was always less than 16 and remained below 1 during most of the summer, suggesting $\mathrm{N}$ limitation from April to late September.

\section{Tissue $\mathrm{N}$ and $\mathrm{P}$ in phytoplankton and macroalgae}

The $\mathrm{N}$ and $\mathrm{P}$ concentrations of particulate matter in the water (the phytoplankton community) ranged from 4.4 and 1.2 to 7.7 and $1.7 \%$ of DW, respectively. Although particulate $\mathrm{N}$ and $\mathrm{P}$ varied significantly with time (Table 1) they showed no clear seasonal patterns (Figs. 2 \& 3). The molar N:P ratios (range: 6.1 to 12.9 ) were constantly below the Redfield ratio of 16 (Redfield et al. 1963), suggesting permanent $N$ limitation of the phytoplankton community. Enrichment with nitro- 


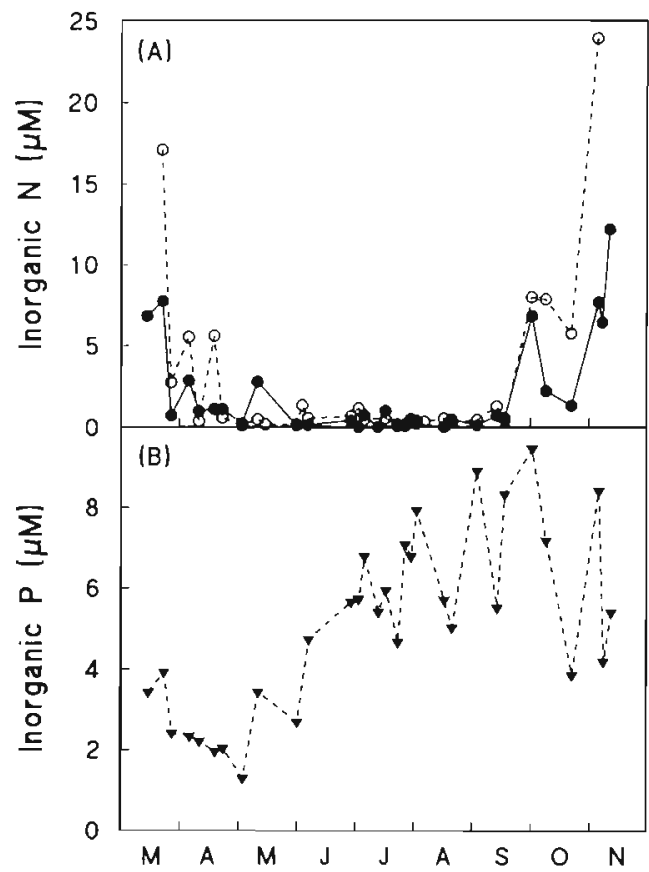

Fig. 1. Seasonal changes in dissolved inorganic nitrogen (DIN) and phosphorus (DIP) in the waters of Roskilde Fjord, Denmark, showing concentrations of $(A)$ ammonium $(\bullet)$ and nitrate $(O)$ and $(B)$ reactive phosphorus ( $)$

gen and phosphorus caused no overall increase in phytoplankton $\mathrm{N}$ or $\mathrm{P}$ contents (Table 1).

There was a strong seasonal effect on the tissue $\mathrm{N}$ content of all 5 macroalgae (Table 1). The $\mathrm{N}$ content was high in spring, decreased to minimum levels in late summer and tended to increase again during autumn (Fig 2). Maximum $N$ concentrations were almost identical among the 4 ephemeral macroalgae (Ulva lactuca, Chaetomorpha linum, Cladophora serica and Ceramium rubrum, 5.5 to $6.0 \%$ of DW), whereas the slow-growing Fucus vesiculosus had a lower maximum value $\left(3.5 \%\right.$ of $D W_{\text {; }}$ see Table 3$)$. Minimum values were almost identical $(1.0 \% \mathrm{~N}$ of DW) among all 5 species. Nitrogen enrichment caused an overall increase in the tissue $\mathrm{N}$ content of all macroalgae but $F$ vesiculosus $(p=0.064$; Table 1$)$.

The tissue $\mathrm{P}$ content also varied seasonally (Table 1) and showed distinct interspecific variations. Nonenriched Fucus vesiculosus had the highest 10.39 to $0.75 \%$ of DW) and Ulva lactuca the lowest $(0.20$ to $0.43 \%$ of DW) P content (Fig. 3). Minimum concentrations were observed during late summer despite high $\mathrm{P}$ availability, suggesting that $P$ acquisition was hampered in $\mathrm{N}$-limited plants. Phosphorus enrichment increased caused an overall increase in $\mathrm{P}$ content among most macroalgae (Table 1).

\section{In situ growth rates and nutrient responses}

The growth rates of the phytoplankton community and all macroalgae varied seasonally (Fig. 4, Table 2). Macroalgal growth peaked during summer when the phytoplankton community grew little or even showed a negative net growth. There was no direct relationship between ambient growth rates and tissue nutrient concentrations. The phytoplankton community showed

Table 1. Effect of time (season) and nutrient enrichment on the tissue $\mathrm{N}$ and P content of different algae in Roskilde Fjord, Denmark

\begin{tabular}{|c|c|c|c|c|c|c|c|c|}
\hline & \multirow[t]{2}{*}{ Factors } & \multirow[t]{2}{*}{$\mathrm{df}$} & \multicolumn{3}{|c|}{ Nitrogen content } & \multicolumn{3}{|c|}{ Phosphorus content } \\
\hline & & & MS & F-ratio & $\mathrm{p}$ & MS & F-ratio & $\mathrm{p}$ \\
\hline \multirow{3}{*}{ Phytoplankton } & Time & 9 & 0.140 & 68.2 & 0.000 & 0.292 & 36.6 & 0.000 \\
\hline & Enrichment & 1 & 0.010 & 3.3 & 0.078 & 0.001 & 0.1 & 0.740 \\
\hline & $\mathrm{T} \times \mathrm{E}$ & 9 & 0.010 & 4.9 & 0.000 & 0.004 & 0.5 & 0.867 \\
\hline \multirow[t]{3}{*}{ Ulva lactuca } & Time & 8 & 1.976 & 1000.0 & 0.000 & 0.601 & 76.3 & 0.000 \\
\hline & Enrichment & 1 & 0.233 & 135.4 & 0.000 & 0.094 & 11.9 & 0.001 \\
\hline & $\mathrm{T} \times \mathrm{E}$ & 8 & 0.009 & 5.5 & 0.000 & 0.019 & 2.4 & 0.032 \\
\hline \multirow[t]{3}{*}{ Cladophora serica } & Time & 9 & 1.305 & 373.1 & 0.000 & 0.870 & 129.4 & 0.000 \\
\hline & Enrichment & 1 & 0.420 & 120.1 & 0.000 & 0.018 & 2.7 & 0.107 \\
\hline & $\mathrm{T} \times \mathrm{E}$ & 9 & 0.003 & 13.1 & 0.000 & 0.013 & 2.0 & 0.068 \\
\hline \multirow[t]{3}{*}{ Ceramium rubrum } & Time & 7 & 1.046 & 416.0 & 0.000 & 0.173 & 36.3 & 0.000 \\
\hline & Enrichment & 1 & 0.476 & 189.4 & 0.000 & 0.040 & 8.3 & 0.007 \\
\hline & $T \times E$ & 7 & 0.066 & 26.3 & 0.000 & 0.005 & 1.2 & 0.358 \\
\hline \multirow[t]{3}{*}{ Chaetomorpha linum } & Time & 7 & 1.290 & 599.0 & 0.000 & 1.098 & 142.8 & 0.000 \\
\hline & Enrichment & 1 & 0.457 & 212.0 & 0.000 & 0.041 & 5.3 & 0.028 \\
\hline & $\mathrm{T} \times \mathrm{E}$ & 7 & 0.033 & 15.1 & 0.000 & 0.011 & 1.4 & 0.025 \\
\hline \multirow[t]{3}{*}{ Fucus vesiculosus } & Time & 9 & 1.308 & 1.7 & 0.123 & 0.269 & 54.0 & 0.000 \\
\hline & Enrichment & 1 & 2.798 & 3.6 & 0.064 & 0.689 & 138.4 & 0.000 \\
\hline & $\mathrm{T} \times \mathrm{E}$ & 9 & 0.722 & 1.0 & 0.123 & 0.052 & 10.5 & 0.000 \\
\hline
\end{tabular}




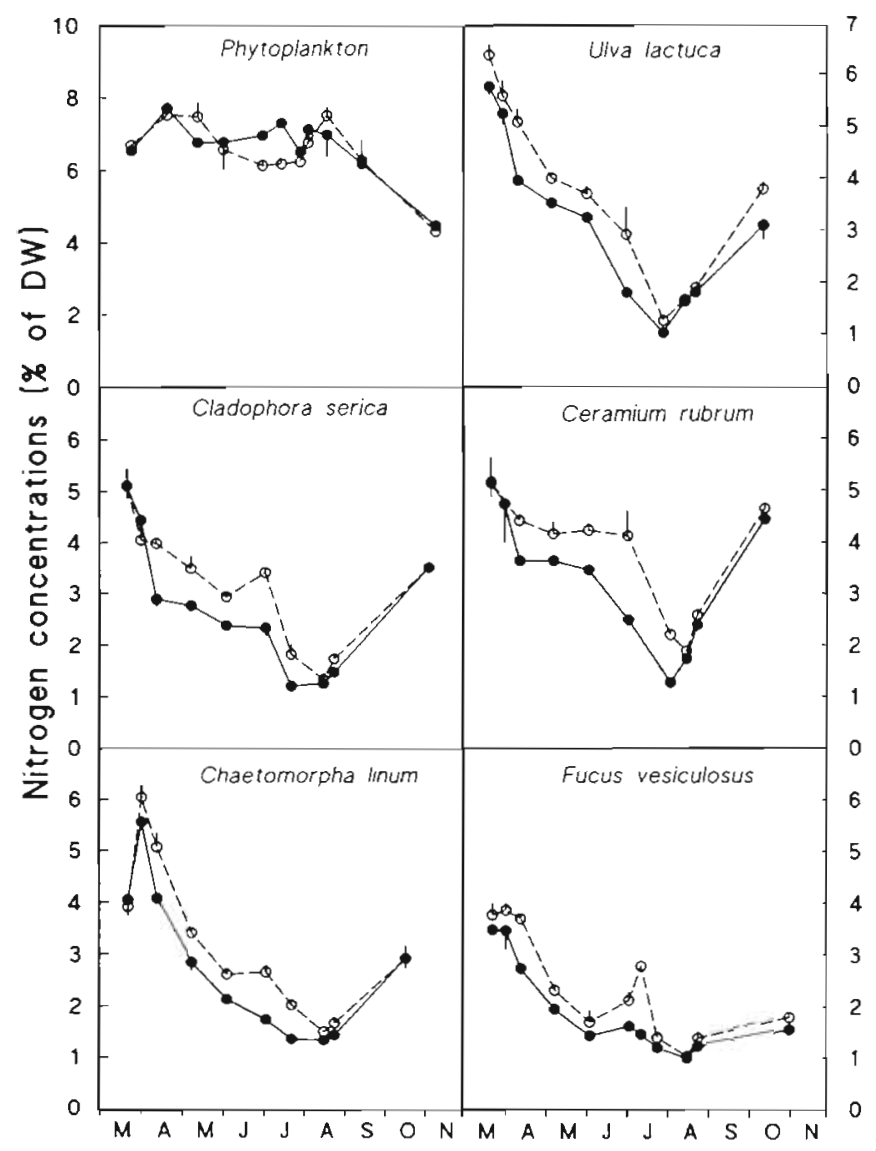

the largest seasonal variation in growth rates (from -0.23 to $0.39 \mathrm{~d}^{-1}$ ): the growth rate of Ulva lactuca ranged from 0.074 to $0.143 \mathrm{~d}^{-1}$ while growth rates were almost similar (range: 0.006 to $0.251 \mathrm{~d}^{-1}$ ) among the 3 filamentous algae (Ceramium rubrum, Cladophora serica and Chaetomorpha linum). Fucus vesiculosus had the slowest growth rate (range: 0.006 to 0.065 $\mathrm{d}^{-1}$ ).

Nitrogen enrichment caused an overall stimulation of growth rates in all algae except for Fucus vesiculosus (Fig. 4, Table 2) Phytoplankton yrowth responded significantly $(p<0.05)$ to $N$ enrichment in all individual experiments except in March, while stimulation by P enrichment was only observed on 1 occasion in April The growth of Ulva lactuca responded signifi-

Fig. 3. Seasonal changes in tissue $\mathrm{P}$ concentrations among the phytoplankton community and 5 species of macroalgae. Points are mean values for control (unennched) ( $\bullet$ ) and for P-ennched (0) algae. Vertical bars represent $\pm 1 \mathrm{SE}(\mathrm{n}=3)$

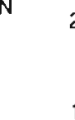

Fig. 2. Seasonal changes in tissue $N$ concentrations among the phytoplankton community and 5 species of macroalgae. Points are mean values for control (unenriched) $(\bullet)$ and for $N$-enriched (0) algae. Vertical bars represent $\pm 1 \mathrm{SE}(\mathrm{n}=3)$

cantly $(p<0.05)$ to $N$ enrichment in 5 individual experiments carried out between May and September, while $P$ enrichment had no effect at all. Ceramium rubrum and Cladophora serica responded almost identically to $N$ enrichment by increasing growth rates significantly $(p<0.05)$ in 3 individual experiments from late July to September, while P enrichment did not stimulate growth. Chaetomorpha linum growth responded significantly $(p<0.05)$ to $N$ enrichment in 2 experiments between mid-July and mid-August. Phosphorus enrichment had no significant effect on $C$. linum growth. The growth of $F$. vesiculosus was only stimulated significantly ( $\mathrm{p}<$ 0.05 ) by $N$ enrichment on 1 occasion in mid-August. while $P$ enrichment had no effects.

Overall, nitrogen was the most important nutrient limiting algal growth under field conditions except for a short period in spring when phosphorus also
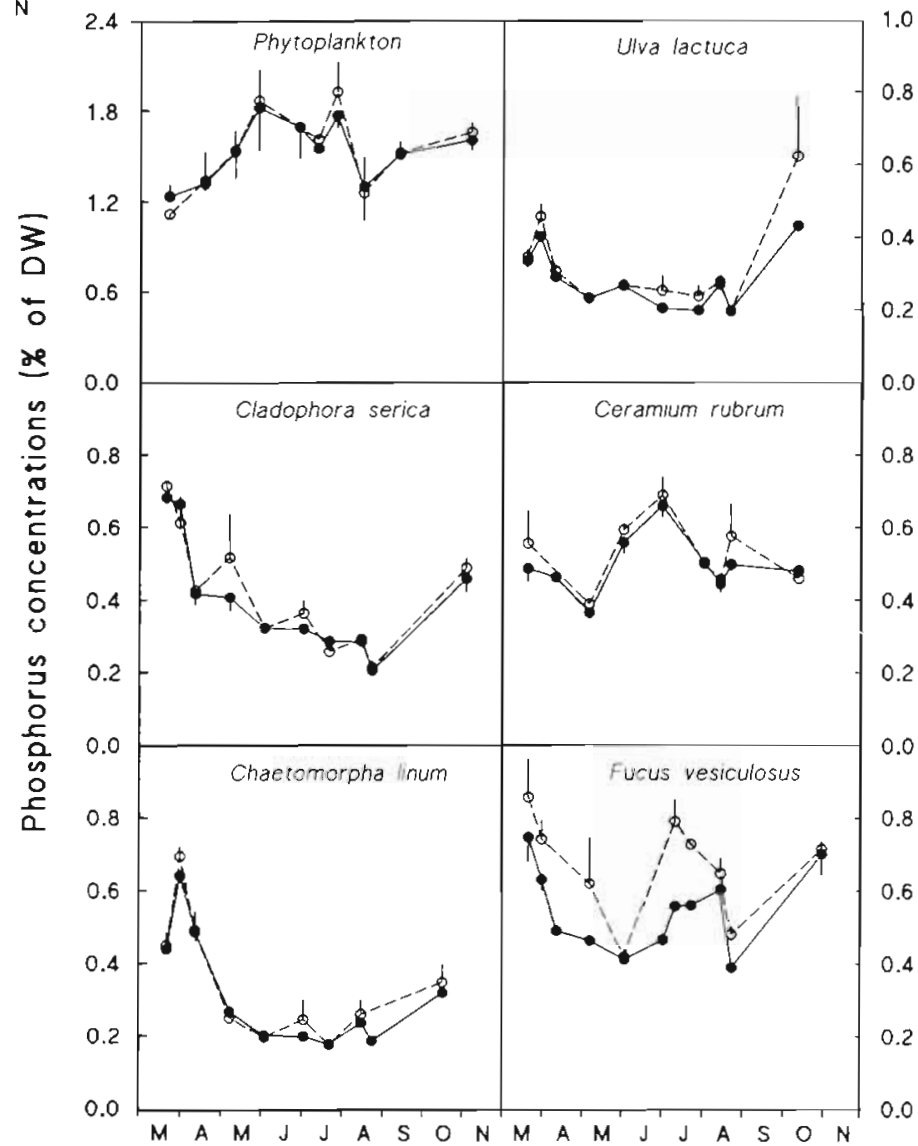
appeared to limit the growth of the phytoplankton community. The fastest-growing algae (the phytoplankton and Ulva lactuca) appeared to be $\mathrm{N}$ limited during most of the period with low $\mathrm{N}$ availability while the slower-growing algae only were $N$ limited towards the end of that period. Thus, fast-growing algae suffered from nutrient shortage during a much longer period than the slowergrowing species.

\section{Laboratory growth experiments}

The algal growth rates obtained over 2 to $8 \mathrm{~d}$ in the laboratory increased asymptotically towards $\mu_{\max }$ with increasing tissue $\mathrm{N}$ content (Fig. 5). The experimentally determined maximum growth rate at high tissue $\mathrm{N}$ concentrations varied 12 -fold among species and was lowest in Fucus vesiculosus $\left(0.039 \mathrm{~d}^{-1}\right)$ and highest in Ulva lactuca $(0.513$ $\left.\mathrm{d}^{-1}\right)$. The subsistence $\mathrm{N}$ quota $\left(N_{\mathrm{Q}}\right)$ varied only little among the 5 macroalgae, ranging from $0.55 \%$ $\mathrm{N}$ of DW in F vesiculosus to $1.02 \%$ of DW in C. rubrum (Table 3). Bootstrapped mean values of the critical $N$ content $\left(N_{C}\right)$ varied 3 -fold from $1.15 \% \mathrm{~N}$ of DW in Chaetomorpha linum to $3.10 \%$ of DW in C. rubrum (Table 3 ).

\section{Nitrogen requirements and storage}

The amount of nitrogen needed to sustain maximum algal growth $\left(\mu_{\max } \times N_{C}\right)$ ranged from

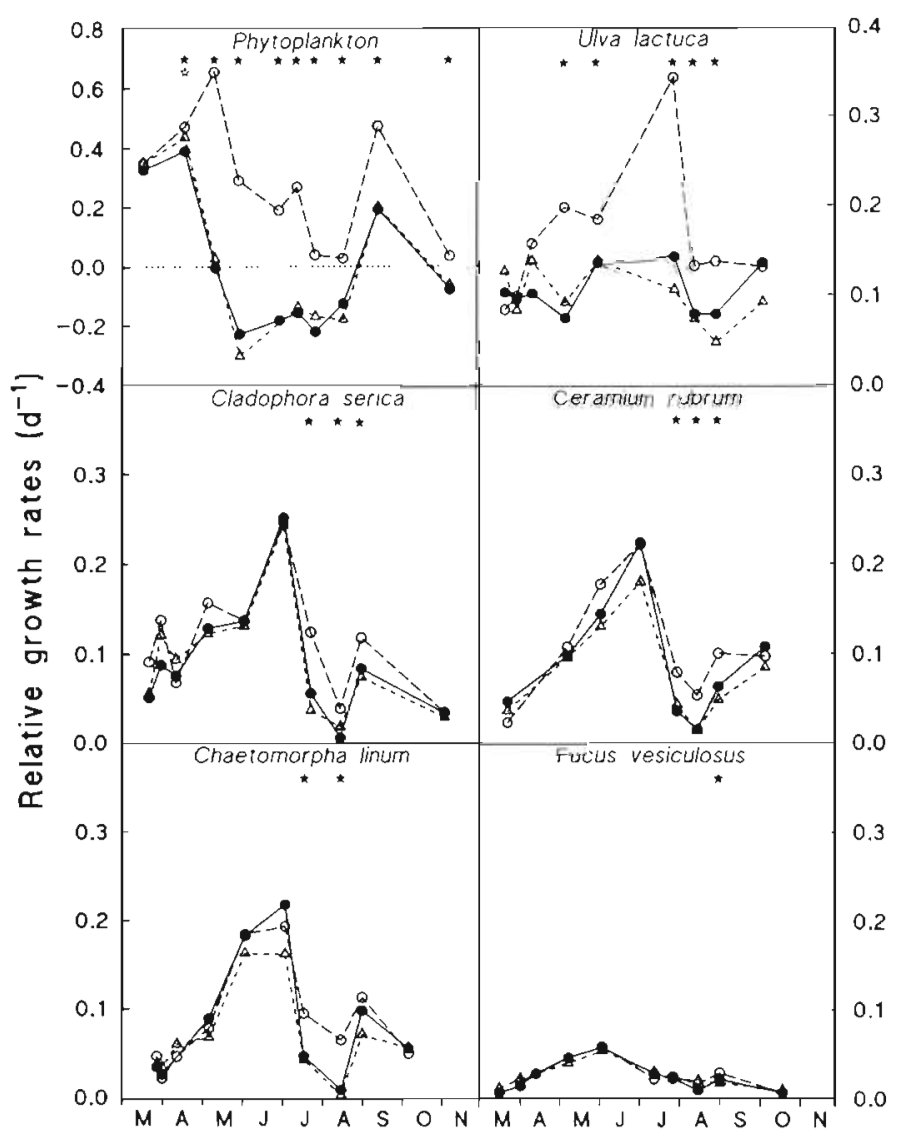

Fig. 4 Seasonal variation in relative growth rates in the phytoplankton community and 5 species of macroalgae measured under ambient (unenriched) conditions $(\bullet$ ), with $\mathrm{N}$ enrichment $(O)$ and with $P$ enrichment $(\Delta)$. ( $\star$ Experiments with a significant $(p<0.05)$ response to $N$ enrichment; $(\theta)$ experiments with a significant response to $P$ enrichment

Table 2. Overall effect of time (season) and nutrient enrichment on the growth rates of different algae in Roskilde Fjord

\begin{tabular}{|c|c|c|c|c|c|c|}
\hline & Factor & df & MS & F-ratio & $\mathrm{p}$ & Range test (Tukey) \\
\hline Phytoplankton & $\begin{array}{l}\text { Time } \\
\text { Enrichment } \\
\mathrm{T} \times \mathrm{E}\end{array}$ & $\begin{array}{r}9 \\
2 \\
18\end{array}$ & $\begin{array}{l}0.333 \\
0.716 \\
0.037\end{array}$ & $\begin{array}{r}252.6 \\
542.8 \\
28.3\end{array}$ & $\begin{array}{l}0.000 \\
0.000 \\
0.000\end{array}$ & $\mathrm{~N}>\mathrm{C} \& \mathrm{P}>\mathrm{C}$ \\
\hline Ulva lactuca & $\begin{array}{l}\text { Time } \\
\text { Enrichment } \\
T \times E\end{array}$ & $\begin{array}{r}8 \\
2 \\
16\end{array}$ & $\begin{array}{l}0.008 \\
0.025 \\
0.004\end{array}$ & $\begin{array}{l}23.1 \\
70.0 \\
11.5\end{array}$ & $\begin{array}{l}0.000 \\
0.000 \\
0.000\end{array}$ & $N>C \& P=C$ \\
\hline Cladophora serica & $\begin{array}{l}\text { Time } \\
\text { Enrichment } \\
\mathrm{T} \times \mathrm{E}\end{array}$ & $\begin{array}{r}9 \\
2 \\
18\end{array}$ & $\begin{array}{l}0.030 \\
0.005 \\
0.001\end{array}$ & $\begin{array}{r}62.8 \\
9.6 \\
1.6\end{array}$ & $\begin{array}{l}0.000 \\
0.000 \\
0.078\end{array}$ & $N>C \& P=C$ \\
\hline Ceramium rubrum & $\begin{array}{l}\text { Time } \\
\text { Enrichment } \\
\mathrm{T} \times \mathrm{E}\end{array}$ & $\begin{array}{r}7 \\
2 \\
14\end{array}$ & $\begin{array}{l}0.027 \\
0.004 \\
0.001\end{array}$ & $\begin{array}{r}92.3 \\
14.2 \\
1.9\end{array}$ & $\begin{array}{l}0.000 \\
0.000 \\
0.058\end{array}$ & $N>C \& P<C$ \\
\hline Chaetomorpha linum & $\begin{array}{l}\text { Time } \\
\text { Enrichment } \\
T \times E\end{array}$ & $\begin{array}{r}7 \\
2 \\
14\end{array}$ & $\begin{array}{l}0.031 \\
0.003 \\
0.001\end{array}$ & $\begin{array}{r}104.0 \\
10.2 \\
2.7\end{array}$ & $\begin{array}{l}0.000 \\
0.000 \\
0.005\end{array}$ & $N>C \& P<C$ \\
\hline Fucus vesiculosus & $\begin{array}{l}\text { Time } \\
\text { Enrichment } \\
T \times E\end{array}$ & $\begin{array}{r}9 \\
2 \\
18\end{array}$ & $\begin{array}{l}0.002 \\
0.000 \\
0.000\end{array}$ & $\begin{array}{r}37.4 \\
0.2 \\
1.5\end{array}$ & $\begin{array}{l}0.000 \\
0.790 \\
0.118\end{array}$ & $N=C \& P=C$ \\
\hline
\end{tabular}




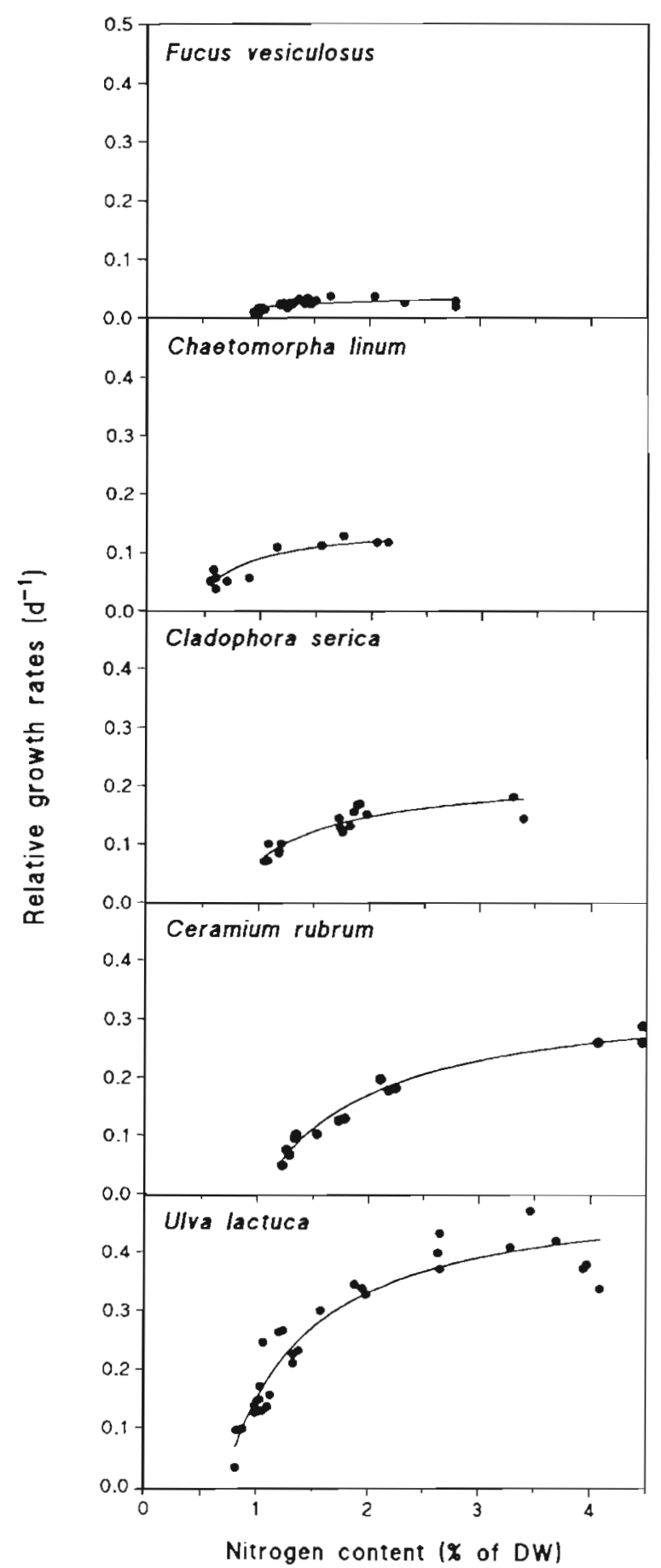

Fig. 5. Growth rates as a function of tissue $\mathrm{N}$ content in 5 specjes of macroalgae. Data points were obtamed in laboratory growth experments and fitted to the Droop expression using non-linear regression. Data for Chaetomorpha linum was redrawn from Pedersen (1994)

$1.2 \mathrm{mg} \mathrm{N}(\mathrm{g} \mathrm{DW})^{-1} \mathrm{~d}^{-1}$ in Fucus vesiculosus to $37.3 \mathrm{mg} N(g \mathrm{DW})^{-1} \mathrm{~d}^{-1}$ in the phytoplankton community (Table 4). The 30-fold range in $\mathrm{N}$ demand was mainly caused by the 10 -fold variation in maximum growth rates among species and secondarily by the smaller interspecific difference in critical $\mathrm{N}$ concentrations.

The amount of nitrogen stored in excess of the critical limit $\left(N_{S}=N_{\max }-N_{C}\right)$ that could support maximum algal growth ranged from 17.7 to $44.2 \mathrm{mg} N(g \mathrm{DW})^{-1}$ among the different algal species, with Chaetomorpha linum apparently having the largest excess $N$ pool (Table 4$)$. The storage capacity $\left(T_{\max }\right)$, defined as the number of days that excess nitrogen $\left(N_{S}\right)$ could support maximum growth, ranged from $0.5 \mathrm{~d}$ for the phytoplankton community to $2-7 \mathrm{~d}$ for the ephemeral macroalgae and $12 \mathrm{~d}$ for Fucus vesiculosus and, thus, varied 25 -fold among the different algae. Algal growth could proceed at reduced rates when the $N$ content decreased below the critical limit $\left(N_{C}\right)$ until the subsistence quota $\left(N_{Q}\right)$ was reached. This internal $N$ pool $\left(N_{\text {Ied }}=N_{C}-N_{Q}\right)$ ranged from $7.8 \mathrm{mg} \mathrm{N}(\mathrm{g} \mathrm{DW})^{-1}$ in $C$. linum to $20.7 \mathrm{mg} \mathrm{N}(\mathrm{g} \mathrm{DW})^{-1}$ in C. rubrum, and could support growth at reduced rates $\left(T_{\text {red }}\right)$ for another $2.6 \mathrm{~d}$

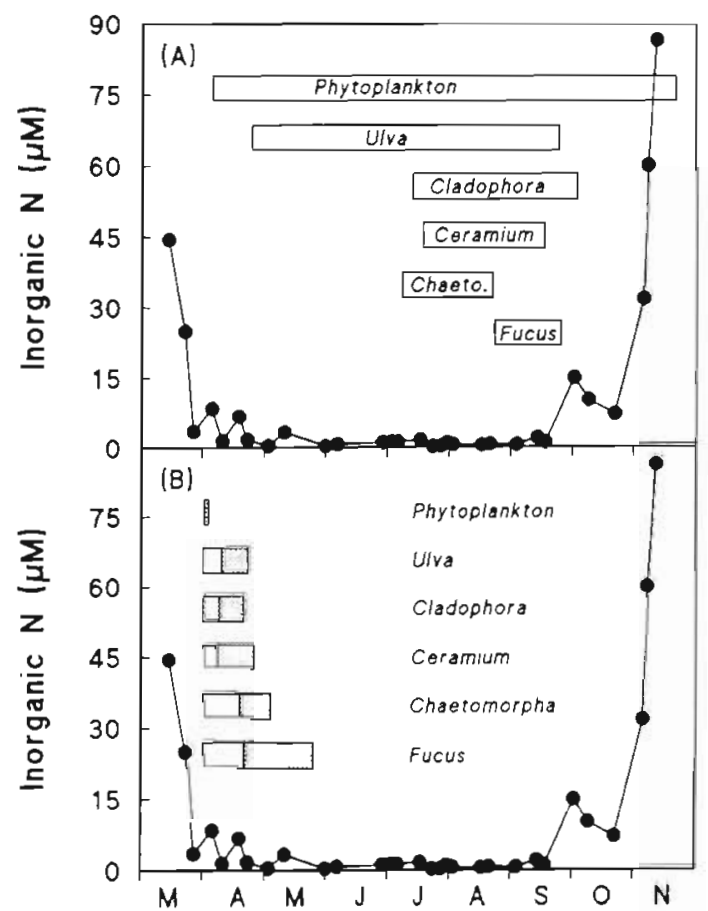

Fig. 6. Temporal extent (horizontal bars) of (A) observed $N$ limitation and (B) $N$ limitation estımated from the $N$ storage capacity of the phytoplankton community and 5 species of macroalgae in Roskilde Fjord. Seasonal variction in dissolved Inorganic nutrogen is shown for comparison ( ). In (B) the estımated periods of maximum (non-nutrient-limited) growth based on internal $N$ reserves and assuming no compensatory $\mathrm{N}$ uptake from the water are represented by open bars while shaded bars are the subsequent periods of reduced (i.e. nutrient-limited) growth untll internal $N$ supplies are exhausted 
Table 3. Observed maximum growth rates $\left(\mu_{\text {max }}\right)$, maximum $\left(N^{*}\right)$ and critical $N\left(N_{C}\right)$ concentrations, and subsistence quota $\left(N_{C_{2}}\right)$ of the algae studied in Roskilde Fjord. Maximum growth rates and $N$ concentrations were obtained from field measurements. Subsistence quotas and critical $\mathrm{N}$ contents were obtained from the laboratory experiments or the literature (in the case of phytoplankton). Numbers are means with $95 \%$ confidence intervals in brackets (values for $N_{c}$ are bias-adjusted bootstrap means with percentile-based confidence intervals)

\begin{tabular}{|c|c|c|c|c|}
\hline & $\begin{array}{l}\mu_{\max } \\
\left(d^{-1}\right)\end{array}$ & $\begin{array}{c}N_{\max } \\
(\% \text { of dry weight) }\end{array}$ & $N_{\mathrm{C}}$ & $N_{Q}$ \\
\hline Phytoplankton & $\begin{array}{c}0.656 \\
\{0.609-0.703\}\end{array}$ & $\begin{array}{c}7.70 \\
(7.53-7.87)\end{array}$ & $\begin{array}{c}5.68^{4} \\
-\end{array}$ & $\begin{array}{c}4.44^{\mathrm{C}} \\
-\end{array}$ \\
\hline Ulva lactuca & $\begin{array}{c}0.343 \\
(0.336-0.350)\end{array}$ & $\begin{array}{c}5.78 \\
(5.36-6.20)\end{array}$ & $\begin{array}{c}2.17 \\
(1.33-2.93)\end{array}$ & $\begin{array}{c}0.71 \\
(0.66-0.76)\end{array}$ \\
\hline Cladophora serica & $\begin{array}{c}0.251 \\
(0.189-0.313)\end{array}$ & $\begin{array}{c}5.10 \\
(4.45-5.75)\end{array}$ & $\begin{array}{c}2.05 \\
(0.93-3.31)\end{array}$ & $\begin{array}{c}0.68 \\
(0.57-0.79)\end{array}$ \\
\hline Ceramium rubrum & $\begin{array}{c}0.223 \\
(0.176-0.270)\end{array}$ & $\begin{array}{c}5.15 \\
(4.50-5.80)\end{array}$ & $\begin{array}{c}3.10 \\
(2.59-3.64)\end{array}$ & $\begin{array}{c}1.02 \\
(0.97-1.075)\end{array}$ \\
\hline Chaetomorpha linum & $\begin{array}{c}0.218 \\
(0.176-0.260)\end{array}$ & $\begin{array}{c}5.56 \\
(4.90-6.21)\end{array}$ & $\begin{array}{c}1.15^{b} \\
(0.96-1.38)\end{array}$ & $\begin{array}{c}0.38^{b} \\
(0.37-0.39)\end{array}$ \\
\hline Fucus vesiculosus & $\begin{array}{c}0.065 \\
(0.003-0.127)\end{array}$ & $\begin{array}{c}3.48 \\
(3.31-3.65)\end{array}$ & $\begin{array}{c}1.71 \\
(-1.48-4.38)\end{array}$ & $\begin{array}{c}0.55 \\
(0.35-0.64)\end{array}$ \\
\hline \multicolumn{5}{|l|}{$\begin{array}{l}\text { aRedfield et al (1963) } \\
\text { bPedersen (1994) }\end{array}$} \\
\hline
\end{tabular}

Table 4. $\mathrm{N}$ requirements at maximum growth $\left(N_{\text {Req }}\right), N$ pools in excess of that necessary for maximum growth $\left(N_{S}\right), N$ pools that allow reduced growth $\left(N_{\text {red }}\right)$, storage capacity at non-limited growth $\left(T_{\mathrm{max}}\right)$, and finally, the possible duration of reduced growth ( $\left.T_{\text {red }}\right)$ based on $N_{\text {red. }}$. Numbers are bias-adjusted bootstrap means with percentile-based $95 \%$ confidence intervals in brackets

\begin{tabular}{|c|c|c|c|c|c|}
\hline & $\begin{array}{c}N_{\text {Req }} \\
\operatorname{mg~N}(g \mathrm{DW})^{-1} \mathrm{~d}^{-1}\end{array}$ & $\begin{array}{l}N_{\mathrm{S}}\left(N_{\max }-N_{\mathrm{C}}\right) \\
\operatorname{mg} N(g \mathrm{DW})^{-1}\end{array}$ & $\begin{array}{l}N_{\text {red }}\left(N_{C}-N_{Q}\right) \\
\operatorname{mg~} N(g D W)^{-1}\end{array}$ & $\begin{array}{l}T_{\max } \\
\text { (d) }\end{array}$ & $\begin{array}{l}T_{\text {red }} \\
\text { (d) }\end{array}$ \\
\hline Phytoplankton & $\begin{array}{c}37.3 \\
-\end{array}$ & $\begin{array}{c}20.8 \\
-\end{array}$ & $\begin{array}{c}32.9 \\
-\end{array}$ & $\begin{array}{l}0.5 \\
-\end{array}$ & 2.6 \\
\hline Ulva lactuca & $\begin{array}{c}7.4 \\
(4.6-10.1)\end{array}$ & $\begin{array}{c}37.6 \\
(5.9-69.6)\end{array}$ & $\begin{array}{c}14.5 \\
(9.1-19.8)\end{array}$ & $\begin{array}{c}3.1 \\
(0.7-5.1)\end{array}$ & $\begin{array}{c}6.5 \\
(6.3-6.6)\end{array}$ \\
\hline Cladophora serica & $\begin{array}{c}5.1 \\
(2.2-8.5)\end{array}$ & $\begin{array}{c}30.5 \\
(17.3-42.5)\end{array}$ & $\begin{array}{c}13.7 \\
(6.0-22.0)\end{array}$ & $\begin{array}{c}3.4 \\
(1.2-6.7)\end{array}$ & $\begin{array}{c}8.7 \\
(7.4-10.9)\end{array}$ \\
\hline Ceramium rubrum & $\begin{array}{c}6.9 \\
(5.3-8.6)\end{array}$ & $\begin{array}{c}20.6 \\
(13.5-26.9)\end{array}$ & $\begin{array}{c}20.7 \\
(17.3-24.4)\end{array}$ & $\begin{array}{c}2.3 \\
(1.5-3.2)\end{array}$ & $\begin{array}{c}9.8 \\
(8.1-12.0)\end{array}$ \\
\hline Chaetomorpha linum & $\begin{array}{c}2.5 \\
(2.0-3.2)\end{array}$ & $\begin{array}{c}44.2 \\
(33.8-49.9)\end{array}$ & $\begin{array}{c}7.8 \\
(6.5-9.2)\end{array}$ & $\begin{array}{c}7.2 \\
(5.7-8.9)\end{array}$ & $\begin{array}{c}10.1 \\
(8.6-12.0)\end{array}$ \\
\hline Fucus vesiculosus & $\begin{array}{c}1.2 \\
(-0.8-3.6)\end{array}$ & $\begin{array}{c}17.7 \\
(-9.9-48.6)\end{array}$ & $\begin{array}{c}11.7 \\
(-9.1-30.1)\end{array}$ & $\begin{array}{c}12.3 \\
(-49.0-73.6)\end{array}$ & $\begin{array}{c}33.6 \\
(-74.1-141.3)\end{array}$ \\
\hline
\end{tabular}

in the phytoplankton community and $34 \mathrm{~d}$ in F. vesiculosus (Table 4).

The importance of internally stored $\mathrm{N}$ for algal performance in Roskilde Fjord can be estimated by calculating the periods during which algal growth can proceed at non-nutrient-limited and reduced rates, respectively, assuming that no external $\mathrm{N}$ supplies are available (Fig. 6). The growth rates applied in these calculations are those rates that were measured for fertilized plants in the field in order to take temperature and light effects on $\mu_{\max }$ into account. The avail- ability of DIN at the study site was low from approximately April 1, and from this date, stored nitrogen could support non-limited phytoplankton growth for 1 d. After another $3 \mathrm{~d}$ of reduced growth, tissue $\mathrm{N}$ concentrations would have declined to the subsistence quota and growth would cease (Fig. 6B). Growth of the ephemeral macroalgae at either nonlimited or reduced rates would cease after 3 to 4 wk, while Fucus vesiculosus would be able to sustain growth for almost 2 mo until the end of May. The discrepancy between the actually observed periods of $\mathrm{N}$ - 
limited growth in the field (Fig. 6A) and growth potentially supported by internal $\mathrm{N}$ reserves suggests that DIN was supplied from more sources than just internal reserves during the field experiment.

\section{DISCUSSION}

This study demonstrated that opportunistic algal species with simple morphology and fast maximum growth rates suffered more from nutrient limitation in Roskilde Fjord than the species with thick thalli, differentiated tissues and a more conservative growth strategy. All the algal species examined were nutrient limited for shorter or Ionger periods during the growth season, but the temporal extent of limitation differed systematically among the different species. The duration of nutrient-limited growth increased with decreasing algal size and increasing maximum growth rate, and the phytoplankton community was the only plant component that showed signs of nutrient limitation during the entire period of low external nutrient availability.

Algal growth was primarily limited by nitrogen while $P$ limitation only occurred during early spring when low irradiance and temperature were more likely to constrain algal growth (Lapointe \& Tenore 1981, Rosenberg \& Ramus 1982). The concentration of inorganic nitrogen and the DIN:DIP ratio in Roskilde Fjord showed considerable seasonal variation, resembling the patterns observed in other temperate, estuarine areas (Wallentinus 1984, Graneli 1987, Pellikaan \& Nienhuis 1988, Lavery \& McComb 1991). The low DIN concentrations $(<1$ to $2 \mu \mathrm{M})$ observed from April to September were insufficient to saturate the $\mathrm{N}$ uptake rates of most phytoplankton (Eppley et al. 1969, Gold. man \& Glibert 1983) and macroalgal species (Wallentinus 1984), suggesting that nitrogen availability could potentially limit plant growth for 5 to 6 mo during summer if $\mathrm{N}$ uptake and growth were directly coupled. In contrast, the DIP concentrations increased during the growth season and were close to or above the saturation level for $P$ uptake in both phytoplankton and macroalgae (Smith \& Kalff 1982, Wallentinus 1984), suggesting that $\mathrm{P}$ limitation could be of only marginal importance.

The tissue $\mathrm{N}$ content reflected the seasonal variation in nitrogen availability and low levels were found during summer when irradiance and growth were high and external $N$ availability low. Similar patterns in tissue $N$ content have been found in other studies of macroalgae (e.g Asare \& Harlin 1983, Wheeler \& Björnsäter 1992) The constantly low $N$ content of the phytoplankton community and the decline in $\mathrm{N}$ content among the macroalgae during spring and summer are the consequence of metabolic demands exceeding nutrient uptake during growth. The P concentration in algal tissues also declined in summer despite high external $P$ availability, suggesting that the uptake and assimilation of DIP was restricted in N-depleted algae, possibly because of low protein content and enzyme activity. This may explain why tissue $\mathrm{N}$ and $\mathrm{P}$ concentrations are often closely related in aquatic plants (Duarte 1992). The tissue $N$ concentrations of all algae periodically declined below the experimentally determined critical concentrations during late spring and summer. However, the different species reached their critical limits at different times, consistent with their variable responses in the form of elevated $N$ content and growth following $\mathrm{N}$ enrichment.

The species-specific differences in the temporal extension of nitrogen limitation were primarily related to the 30 -fold range in $\mathrm{N}$ requirements per unit biomass and time as determined by the variable growth rates and the differences in the internal $\mathrm{N}$ concentrations needed to sustain growth. Large and morphologically more complex algal species with differentiated tissues have lower intrinsic growth rates than small, unicellular or sheet-formed species (Littler \& Littler 1980, Nielsen \& Sand-Jensen 1990, Duarte 1995). We found a 10 -fold range in maximum growth rates among the algal species and, if the critical nitrogen content had been the same for all species, nitrogen requirements would similarly have varied 10 -fold. The differentiation of tissues into meristematic, photosynthetic and supportive tissues in the slower-growing species, however, seems to reduce the need for internal nutrient concentrations to sustain growth. In algae without tissue differentiation all cells must have a complete physiological apparatus to support resource acquisition, photosynthesis and growth and, therefore, should contain high levels of $\mathrm{N}$ - and P-rich organic compounds This hypothesized, systematic difference in the need for nutrients is consistent with the observed differences in critical nutrient content among species (Fujita 1985, this study) and with the general relationships between nutrient contents and morphology or growth rate found among aquatic plants (Duarte 1992, 1995). In our study the critical $N$ content was 2 - to 3 -fold higher for the fast-growing species and, hence, the total $N$ requirements per unit biomass and time exhibited the 30 -fold range.

The pool size of nitrogen stored internally in excess of immediate demands was, however, about the same for all species and, hence, did not explain further the differences in the extent of nitrogen limitation. We found the highest maximum tissue $\mathrm{N}$ and $\mathrm{P}$ concentrations among the fast-growing algae and the lowest in the slow-growing Fucus vesiculosus as also observed by Fujita (1985) and Wheeler \& Bjornsäter (1992). As 
pointed out by Wheeler \& Björnsäter (1992), nutrient storage cannot, however, be evaluated from maximum concentrations alone, because interspecific variations in the critical $N$ concentrations and growth rates influence the size of the storage pool and, hence, the storage capacity measured in time. We found no systematic variation in the size of the storage pool among fast- and slow-growing algae and, therefore, any differences in storage capacity were set by the different $\mathrm{N}$ requirements for growth.

Nitrogen limitation was predicted to occur after $0.5 \mathrm{~d}$ (corresponding to ca 0.5 doubling times) of maximum growth in the phytoplankton community and after $12 \mathrm{~d}$ (ca 1 doubling time) in Fucus vesiculosus, and growth would cease after another 2.6 to $34 \mathrm{~d}$ (ca 4 doubling times) depending on algal species, assuming no uptake of DIN from the water. These results are comparable to those of Fujita (1985), who found that stored nitrogen could support growth of Ulva lactuca, Enteromorpha sp. and Gracilaria tikvahiae for 6, 8 and $14 \mathrm{~d}$, respectively, in culture experiments with restricted external $\mathrm{N}$ availability. When including the effect of seasonal changes in light and temperature on maximum growth rates in the field, we predicted that internal $N$ reserves could support growth of $F$. vesiculosus for a total of $54 \mathrm{~d}$. This agrees with studies on kelps showing that growth can proceed for long periods (months) of low external nutrient availability based on stored N pools (Chapman \& Craigie 1977, Zimmerman $\&$ Kremer 1986). The onset of $N$ limitation in Roskilde Fjord was delayed relative to the predicted onset of limitation and this delay was likely caused by uptake of DIN from the water column. We assumed that the external DIN sources were totally depleted but the low DIN concentrations present during summer would allow some nitrogen to be taken up by the algae (Wallentinus 1984). Nutrient uptake per unit of biomass is much faster in small algae with large surface area to volume ratios than in large species with thick thalli (Wallentinus 1984, Hein et al, 1994), but, apparently, the fast uptake could not fulfill the high nutrient requirements for growth and prevent nitrogen limitation from occurring also among the species with simple morphology

The present work adds to a functional explanation for the qualitative changes in plant communities observed with increased eutrophication. Low availability of dissolved inorganic nutrients in shallow coastal waters during summer restricts the growth rate and, hence, the abundance of phytoplankton and ephemeral macroalgae, while slow-growing, perennial macroalgae can sustain near to maximum growth rates during most of the summer based on a combination of low nutrient requirements, stored nutrients and nutrients taken up from the water column. Although phyto- plankton and ephemeral macroalgae may still grow faster when limited by nutrients than perennial macroalgae, they also experience higher loss rates (Duarte 1995). We can, therefore, with some reason assume that differences in loss rates balance differences in intrinsic growth rates, resulting in a competitive advantage for plants not limited by nutrient availability. The growth strategy of the opportunistic algal forms allows them to exploit a suddenly occurring richness in resource availability so that they can escape grazing control and, in a short time, built up high biomasses. However, the populations will collapse when resources are depleted and only a continuous supply of nutrients will allow them to dominate the autotrophic communities of shallow coastal waters more permanently. In contrast, the more conservative growth strategy of perennial kelps and fucoids is ecologically advantageous in physically stable environments with restricted but predictable nutrient resource availability.

Acknowledgements. This study was supported by a HAV-90 grant from the Danish National Agency of Environmental Protection. We acknowledge B. Kjøller for valuable assistance during field work and laboratory experiments, and thank $\mathrm{K}$ Sand-Jensen for constructive criticism during all phases of this work. This is contribution 652 from the Freshwater Biological Laboratory, University of Copenhagen.

\section{LITERATURE CITED}

Asare SO, Harlin MM (1983) Seasonal fluctuations in tissue nitrogen for five species of perennial macroalgae in Rhode Island Sound. J Phycol 19:254-257

Banse K (1976) Rates of growth, respiration and photosynthesis of unicellular algae as related to cell size - a review. $J$ Phycol 12:135-140

Borum J (1983) The quantitative role of macrophytes, epiphytes and phytoplankton under different nutrient conditions in Roskilde Fjord, Denmark. Proc Int Symp Aquat Macrophytes, Faculty of Science, University of Nijmegen, p $35-40$

Borum J (1985) Development of epiphytic communities on eelgrass (Zostera marina) along a nutrient gradient in a Danish estuary. Mar Biol 87:211-218

Boynton WR, Kemp WM, Keefe CW (1982) A comparative analysis of nutrients and other factors influencing estuarine phytoplankton production. In: Kennedy VS (ed) Estuarine comparisons. Academic Press, New York, p 69-90

Brinkhuis JC (1977) Comparison of salt-marsh fucoid production estimated from three different indices. J Phycol 13 $328-335$

Burkholder JM. Mason KM, Glasgow HB Jr (1992) Watercolumn nitrate enrichment promotes decline of eelgrass Zostera marina: evidence from seasonal mesocosm experiments. Mar Ecol Prog Ser 81:163-178

Cambridge ML, McComb AJ (1984) The loss of seagrasses in Cockburn Sound, Western Australia. I. The time course and magnitude of seagrass decline in relation to industrial development. Aquat Bot 20:229-243

Cebrián J, Duarte CM (1994) Growth-dependent herbivory in natural plant communities. Funct Ecol 8:518-525

Chapman ARO, Craigie JS (1977) Seasonal growth in Lami- 
naria longicruris: relations with dissolved inorganic nutrients and internal reserves of nitrogen. Mar Biol 40:197-205

Droop MR (1983) 25 years of algal growth kinetucs: a personal view. Botanica Mar 26:99-112

Duarte CM (1992) Nutrient concentration of aquatic plants: patterns across species. Limnol Oceanogr 37:882-889

Duarte CM (1995) Submerged aquatic vegetation in relation to different nutrient regimes. Ophelia 41:87-112

Efron B, Tibshirani R (1986) Bootstrap methods for standard errors, confidence intervals, and other measures of statistical accuracy. Stat Sci 1:54-77

Eppley RW, Rogers JN, McCarthy JJ (1.969) Half-saturation constants for uptake of nitrate and ammonium by marine phytoplankton. Limnol Oceanogr 19:912-920

Fong P, Zedler JB, Donohoe RM (1993) Nitrogen vs phosphorus limitation of algal biomass in shallow coastal lagoons. Limnol Oceanogr 38:906-923

Fujita RM (1985) The role of nitrogen status in regulating transient ammonium uptake and nitrogen storage by macroalgae. J Exp Mar Biol Ecol 92:283-301

Goldman JC, Glibert PM (1983) Kinetics of inorganic nitrogen uptake by phytoplankton. In: Carpenter EJ, Capone DG (eds) Nitrogen in the marine environment. Academic Press, New York, p 233-274

Graneli E (1987) Nutrient limitation of phytoplankton in a brackish water bay highly influenced by river discharge. Estuar Coast Shelf Sci 25:555-565

Hanisak MD (1979) Nitrogen limitation of Codium fragile spp. tomentosoides as determined by tissue analysis. Mar Biol 50:333-337

Hein M, Pedersen MF, Sand-Jensen K (1994) Size-dependent nitrogen uptake in micro- and macroalgae. Mar Ecol Prog Ser 118:247-253

Kautsky N, Kautsky H, Kautsky U, Waern M (1986) Decreased depth penetration of Fucus vesiculosus (L.) since the 1940s indicates eutrophication of the Baltic Sea. Mar Ecol Prog Ser 28:1-8

Lapointe BE, Tenore KR (1981) Experimental outdoor studies with Ulva fasciata Delile. I. Interaction of light and nitrogen on nutrient uptake, growth, and biochemical composition. J Exp Mar Biol Ecol 53:135-152

Lavery PS, McComb AJ (1991) The nutrutional eco-physiology of Chaetomorpha linum and Ulva rigida in Peel Inlet, Western Australia. Botanica Mar 34:251-260

Littler MM, Littier DS (1980) The evolution of thallus form and survival strategies in benthic marme macroalgae: field and laboratory tests of a functional form model. Am Nat $116: 25-44$

Meyer JS, Ingersoll CG, McDonald LL, Boyce MS (1986) Estimating uncertainty in population growth rates: jackknife vs bootstrap techniques. Ecology 67:1156-1166

Neundorpher JV, Kemp WM (1993) Nitrogen versus phosphorus enrichment of brackish waters: response of the submerged plant Potamogeton perfoliatus and its associated algal communities. Mar Ecol Prog Ser 94:71-82

Nielsen SL, Sand-Jensen K (1990) Allometric scaling of maximal photosynthetic growth rate to surface/volume ratio. Limnol Oceanogr 25:177-180

Odum EP, Kuenzler EJ, Blunt MX (1958) Uptake of ${ }^{32} \mathrm{P}$ and primary productivity in marine benthic algae. Limnol Oceanogr 3:340-345

Orth RJ, Moore KA (1983) Chesapeake Bay: an unprecedented decline in submerged aquatic vegetation. Science $222: 51-53$
Pedersen CB (1994) Vœkstregulerende faktorer, vokststrategi og $\mathrm{N}$-husholdnung i relation til masseforekomst af Chaetomorpha linum i Roskilde Fjord. MS thesis, Freshwater Biological Laboratory, University of Copenhagen

Pedersen MF, Borum J (1992) Nitrogen dynamics of eelgrass Zostera marina during a late summer period of high growth and low nutrient availability. Mar Ecol Prog Ser 80:65-73

Pedersen MF, Borum J (1993) An annual nitrogen budget for a seagrass Zostera manna population. Mar Ecol Prog Ser 101:169-177

Pellikaan GC, Nienhuis PH (1988) Nutrient uptake and release during growth and decomposition of eelgrass, Zostera marina L., and its effects on the nutrient dynamics of Lake Grevelingen. Aquat Bot 30:189-214

Redfield AC, Ketchum BA, Richards FA (1963) The influence of organisms on the composition of sea-water. In: Hill $M N$ (ed) The sea, Vol II. Wiley, London, p 26-77

Reynolds C (1984) The ecology of freshwater phytoplankton. Cambridge University Press, Cambridge

Rosenberg G, Ramus J (1982) Ecological growth strategies in the seaweeds Gracilaria folifera (Rhodophyceae) and Ulva sp. (Chlorophyceae): soluble nitrogen and reserve carbohydrate. Mar Biol 66:251-259

Sand-Jensen K, Borum J (1991) Interactions among phytoplankton, periphyton, and macrophytes in temperate freshwaters and estuaries. Aquat Bot 41:137-175

Sfriso A, Marcomini A, Pavoni B (1987) Relationships between macroalgal biomass and nutrient concentrations in a hyper eutrophic area of the Venice lagoon. Mar Environ Res 22:297-312

Shuter BJ (1978) Size dependence of phosphorus and nitrogen subsistence quotas in unicellular microorganisms. Limnol Oceanogr 23:1248-1255

Smith REH, Kalff J (1982) Size-dependent phosphorus uptake kinetics and coll quota in phytoplankton. J Phycol 18 $275-284$

Solorzano L (1969) Determination of ammonia in natural waters by the phenolhypochlorite method. Limnol Oceanogr $14: 799-801$

Strickland JDH, Parsons TR (1968) A practical handbook of seawater analysis. Bull Fish Res Bd Can 167

Taylor DI, Nixon SW, Granger SL, Bucley BA, McMahon JP, Lin HJ (1995) Responses of coastal lagoon plant communities to different forms of nutrient enrichment - a mesocosm experiment. Aquat Bot 52:19-34

Twilley RR, Kemp WM, Staver KW, Stevenson JC, Boynton WR (1985) Nutrient enrichment of estuarine submersed vascular plant communities. I. Algal growth and effects on production of plants and associated communities. Mar Ecol Prog Ser 23:179-191

Wallentinus I (1984) Comparisons of nutrient uptake rates for Baltic macroalgae with different thallus morphologies. Mar Biol 80:215-225

Wheeler PA, Björnsäter BR (1992) Seasonal fluctuations in tissue nitrogen, phosphorus, and 'v:P for ture macroalgal species common to the Parific Northwest coast. J Phycol $28: 1-6$

Wintermans JFGM, De Motts A (1965) Spectrophotometric characteristics of chlorophyll $a$ and $b$ and their pheophytins in ethanol. Biochim Biophys Acta 109:448-453

Zimmerman RC. Kremer JN (1986) In situ growth and chemical composition of the giant kelp, Macrocystis pyrifera: response to temporal changes in ambient nutrient availabılity. Mar Ecol Prog Ser 27:277-285

Manuscript first recelved: February 12, 1996

Revised version accepted: August 28, 1996 